\title{
Drowned carbonate platforms in the Bismarck Sea, Papua New Guinea
}

\author{
Gary Hoffmann • Eli Silver $\cdot$ Simon Day • \\ Neal Driscoll $\cdot$ Bruce Appelgate
}

Received: 11 June 2009/Accepted: 5 January 2010/Published online: 22 January 2010

(c) The Author(s) 2010. This article is published with open access at Springerlink.com

\begin{abstract}
Extinct volcanic islands in the Bismarck volcanic arc are fringed by well-developed coral reefs. Drowned platforms offshore from these islands provide evidence for subsidence in the central section of the arc, north of the Finisterre Terrane-Australia collision. Bathymetric and backscatter data collected onboard the R/V Kilo Moana in 2004 reveal regularly spaced ( $200 \mathrm{~m}$ interval) drowned platforms at depths as much as $1,100 \mathrm{~m}$ below sea level. However, the adjacent mainland coast has well documented raised terraces indicating long-term uplift. Local subsidence may be due to cessation of magmatic activity and cooling, flexural loading by the uplifting Finisterre Range, loading by nearby active volcanic islands, and/or sediment loading on the seafloor north of the Finisterre Range. We present some simple models in order to test whether flexural loading can account for local
\end{abstract}

G. Hoffmann $(\bowtie) \cdot$ E. Silver

University of California at Santa Cruz, 1156 High St.,

Santa Cruz, CA 95064, USA

e-mail: garyh@pmc.ucsc.edu

E. Silver

e-mail: esilver@pmc.ucsc.edu

S. Day

Aon Benfield Hazard Research Centre, Department of Earth

Sciences, University College London, Gower Street,

London WC1E 6BT, UK

e-mail: simonday_ucl@yahoo.co.uk

N. Driscoll · B. Appelgate

Scripps Institute of Oceanography, 9500 Gilman Dr., La Jolla, CA 92093, USA

e-mail: ndriscoll@ucsd.edu

B. Appelgate

e-mail: tba@ucsd.edu subsidence. We find that volcanic and sedimentary loading can explain the inferred relative subsidence.

Keywords Drowned carbonate platforms .

Papua New Guinea · Flexural modeling · Sidescan sonar

\section{Introduction}

The creation of submerged carbonate platforms requires a rare combination of relatively rapid subsidence and rapid sea-level rise (Darwin 1897; Campbell 1984). Such platforms have been observed around the Hawaiian Islands (Moore and Campbell 1987; Grigg et al. 2002), in the Solomon Sea, Papua New Guinea (Davies et al. 1987a; Galewsky et al. 1996; Webster et al. 2004), in New Zealand (Stern and Holt 1994), and elsewhere. Subsidence in Hawaii was caused primarily by flexural volcanic loading (Campbell 1984), with the platforms tilting landward towards the locus of loading (Moore and Campbell 1987). In the Solomon Sea, however, subsidence was due to flexural loading of the subducting Australian plate by the overriding South Bismarck Plate, resulting in seaward tilting (Davies et al. 1987b; Abbott et al. 1994; Galewsky et al. 1996; Galewsky 1998; Wallace et al. 2004; Webster et al. 2004).

We present observations of submerged platforms around volcanic islands in the Bismarck Volcanic Arc. Unlike the Hawaiian and Solomon Sea submerged platforms, these newly observed platforms are found in an arc volcanic environment on the overriding tectonic plate. In the Bismarck Volcanic Arc, there are several possible causes of subsidence: (1) flexural loading by nearby active arc volcanoes, (2) flexural loading by accumulated sediment deposition, and (3) fore-arc flexural subsidence caused by 
uplift of the overriding Bismarck Sea plate, the mirror image of the flexural bulge on the lower plate.

We present a series of models for the submerged platforms around Bagabag Island, covering a range of possible elastic thicknesses, including volcanic loading, sedimentary loading, and buoyant uplift loading. We find that loading by nearby volcanic islands in combination with relatively high sedimentation rates adequately explains the magnitude of relative subsidence required to create the submerged platforms.

\section{Background}

Hawaiian drowned platforms

Campbell (1984) reported two submerged carbonate platforms on the Kohala Terrace to the northwest of Hawaii based on bottom photography, SeaMARC II sidescan and bathymetry, seismic reflection profiles, and bottom samples. In profile, the reefs were observed to have a shallow, wide bulge at the rim of the terrace. Campbell reported that the reefs formed in situ in shallow water. Jones (1995) provided an age estimate for the $1,000 \mathrm{~m}$ deep reef of $\sim 250 \mathrm{ka}$ based on Electron Spin Resonance measurements of samples collected from the reef.

Jones (1995) expanded on Campbell's (1984) model of platform-drowning on the flanks of volcanoes. First, as the volcano is building and subsiding due to flexural loading of the underlying lithosphere, shallow-water reefs can grow offshore of a relatively stable shoreline during periods of glacial accumulation and sea-level fall. During rapid sealevel rise in a subsequent interglacial period, the carbonate platforms can be submerged to sufficient depths such that reef-growth ceases. This process repeats itself when reef growth continues upslope during a later glacial maximum.
Thus, as the volcano grows and subsides over time, a series of drowned reef platforms can form on its flanks.

\section{Huon Gulf, Papua New Guinea}

The Finisterre terrane of Papua New Guinea began colliding with the New Guinea mainland 3.0-3.7 Ma along the Ramu-Markham Fault (Abbott et al. 1994). The Huon Gulf lies in the zone of eastward propagation where the arc-continent collision transitions into northward subduction of the Solomon Sea plate at the New Britain Trench (Fig. 1). Davies et al. (1987a), Galewsky et al. (1996), and Webster et al. (2004) described a series of submerged pinnacle carbonate platforms and drowned shallow-water reefs on the under-riding plate in the Huon Gulf. In MR1 sidescan imagery, the platforms appear as a sinuous line of high backscatter, which corresponds to the platform rim (Fig. 2). The $\sim 2,000 \mathrm{~m}$ of subsidence of the drowned platforms in the Huon Gulf was caused by loading of the Australian margin by the overriding South Bismarck plate.

\section{Volcanic terraces and flat-topped cones}

Submarine terraces can also form on the flanks of volcanoes by purely volcanic processes. Geist et al. (2008) described a series of terraces on the Galapagos platform up to 3,500 m deep. The escarpments surrounding the terraces are $\sim 300 \mathrm{~m}$ high on average, with slopes of $\sim 24^{\circ}$. Based on sidescan imagery and dredges, they reported that the terraces are composed of basalt. These terraces appear scalloped in morphology, unlike the more continuous edges of the Huon Gulf terraces.

In the vicinity of Hawaii, basaltic flat-topped volcanic cones have been imaged and sampled (Clague et al. 2000). These cones occur near submarine rift zones, and are similar to flat-topped cones found near mid-ocean ridges, such as those shown by Fornari and Campbell (1987). The
Fig. 1 Location map of the Bismarck Volcanic Arc, Papua New Guinea

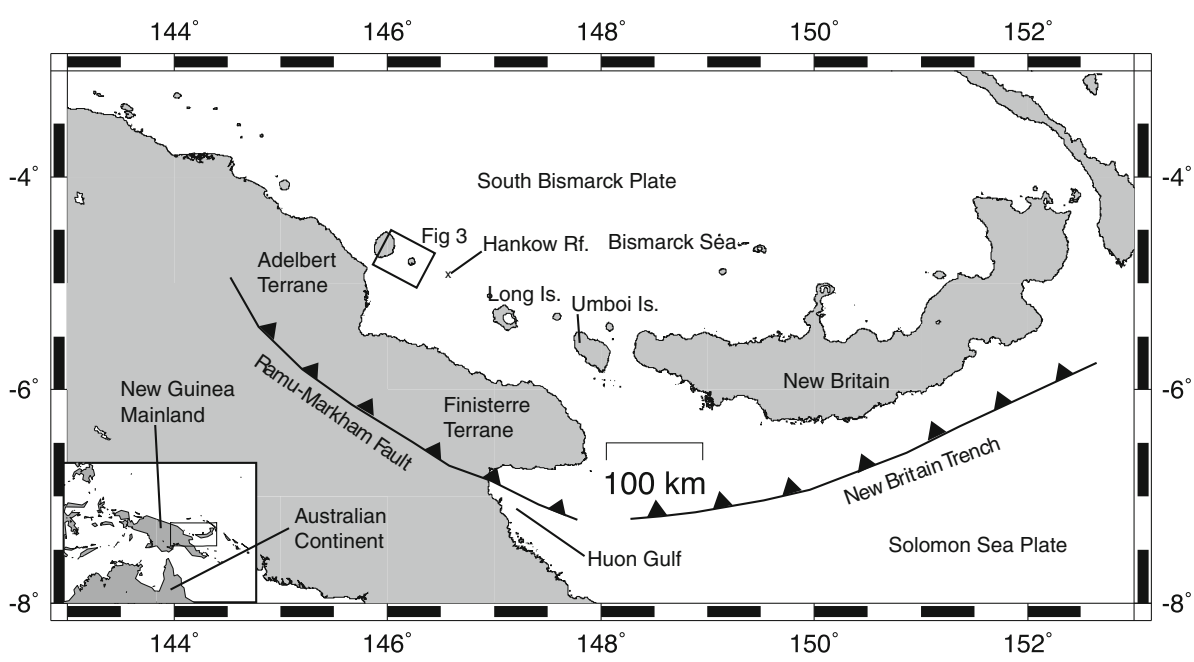




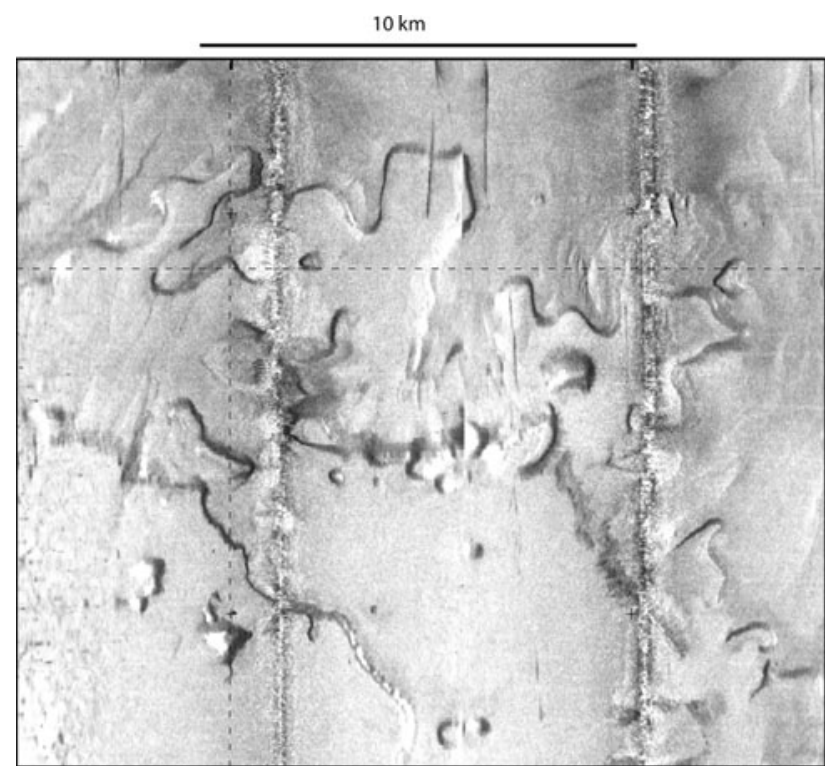

Fig. 2 Sidescan mosaic of drowned carbonate platforms in the Huon Gulf, Papua New Guinea. Modified from Galewsky et al. (1996)

basal diameter of flat-topped cones can be as large as $8 \mathrm{~km}$, although the mean diameter is $\sim 3 \mathrm{~km}$. They can be several hundred meters high, often with a broad, shallow rim that can make them appear morphologically similar to reef systems. However, flat-topped cones are not multi-tiered, as are many drowned reef structures.

\section{Bismarck Volcanic Arc, Papua New Guinea}

The Bismarck Volcanic Arc lies north of the collision of the Finisterre Terrane with the Australian continent in the west, and subduction of the Solomon Sea plate in the east (Fig. 1; Pigram and Davies 1987; Abbott et al. 1994). Although subduction has ceased beneath the western half of the arc, volcanism continues (Johnson et al. 1972). The velocity of the Finisterre collision increases rapidly eastward from the nearby pole of rotation (Tregoning 2002; Wallace et al. 2004). Bagabag Island is located to the north and slightly east of this pole of rotation where the convergence rate is $\sim 20 \mathrm{~mm} /$ year. Bagabag Island is extinct and is fringed by reefs around its entire coast, and is located just east of Karkar Island, a highly active volcano (McKee et al. 1976).

\section{Observations}

Observational methods

We conducted a geophysical survey of the Bismarck Volcanic Arc in November-December 2004 aboard the R/V Kilo Moana. We collected bathymetric data using a hull- mounted 12 kHz Simrad EM120 multibeam echosounder, and backscatter data using a towed $12 \mathrm{kHz}$ Hawaii MR1 sidescan sonar, which has a slightly wider swath width. Additionally, the slant-range correction of the sidescan data assumed a planar bottom, and therefore does not account for rapidly changing topography. Because of this assumption and the fact that the sidescan system was towed, whereas the multibeam system was hull-mounted, there may be misregistration between the sidescan and multibeam data, in particular on steep slopes.

The multibeam bathymetry data are noisy towards the edges of the swath. Noise was particularly problematic around the flanks of volcanic islands, where the rapidly decreasing depth precluded overlapping swaths. Thus, we can use the bathymetric data for general indications of the depths of features on the submarine flanks of volcanic islands, but the noise prevents detailed analysis.

\section{Observational results}

Bagabag Island lies near Karkar Island atop a gently northdipping seafloor ranging from about $1,600 \mathrm{~m}$ deep to $1,800 \mathrm{~m}$ deep in its vicinity (Fig. 3). A series of platforms, denoted the Bagabag Platforms, lies about $8 \mathrm{~km}$ to the southwest of Bagabag Island. The diameter of the Bagabag Platforms is $12.4 \mathrm{~km} \mathrm{E}-\mathrm{W}$ and $8.8 \mathrm{~km} \mathrm{~N}-\mathrm{S}$. The sides of these platforms slope $25-30^{\circ}$ up to terraces at depths of 1,100, 950, 800, and $600 \mathrm{~m}$ (Fig. 4). In sidescan imagery, the sides of these platforms are high backscatter features (Fig. 5).

Grieg Bank begins about $16 \mathrm{~km}$ north of Bagabag Island (Fig. 3). The bank consists of a two-peaked conical edifice about $1 \mathrm{~km}$ tall, followed by a semi-distinct edifice that

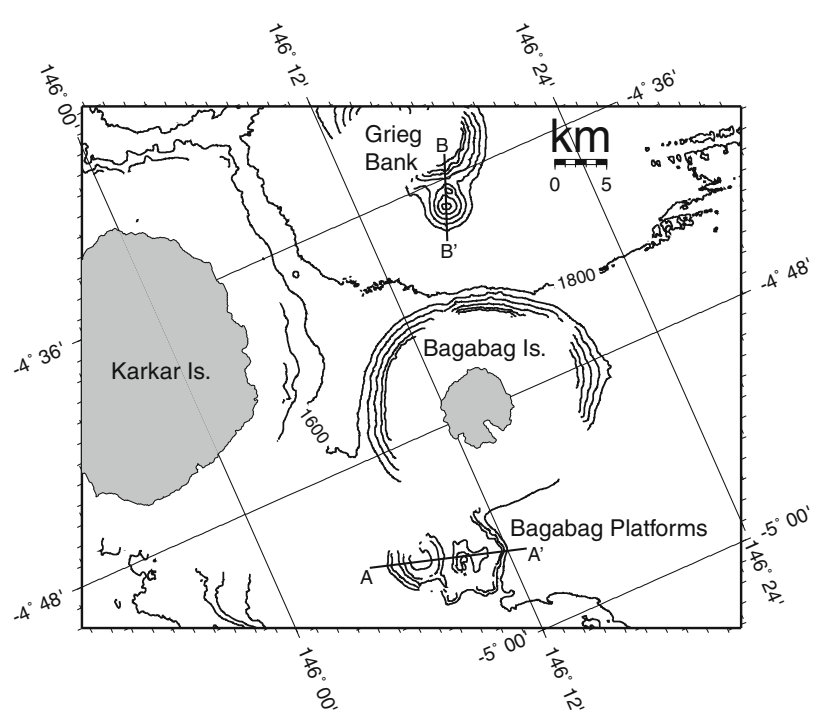

Fig. 3 Bathymetry around Bagabag Island. Contour interval is $200 \mathrm{~m}$ 


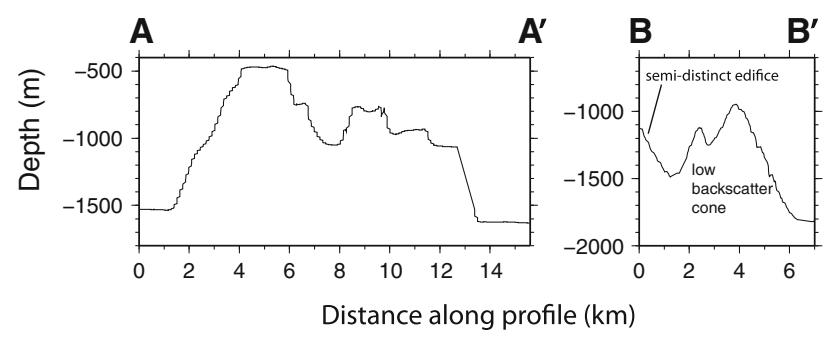

Fig. 4 Bathymetric profiles of Bagabag Platforms (left) and Grieg Bank (right). Location of profiles shown in Figs. 3 and 5. Same horizontal and vertical scales in each figure. Vertical exaggeration $=11$ rises to an active shallow-water reef about $25 \mathrm{~km}$ north of Bagabag Island (Figs. 3, 4). The southern conical edifice of Grieg Bank is relatively uniform and low backscatter (Figs. 4, 5). The larger edifice of Grieg Bank consists of a series of high backscatter, slightly sinuous lineations. These lineations are roughly slope-perpendicular and $\sim 0.5-2 \mathrm{~km}$ apart.

A series of concentric, slightly sinuous, high backscatter lineations lies on the flanks of Bagabag Island (Fig. 5). These features are roughly slope-perpendicular and up to $900 \mathrm{~m}$ deep. Up to five of these concentric high backscatter

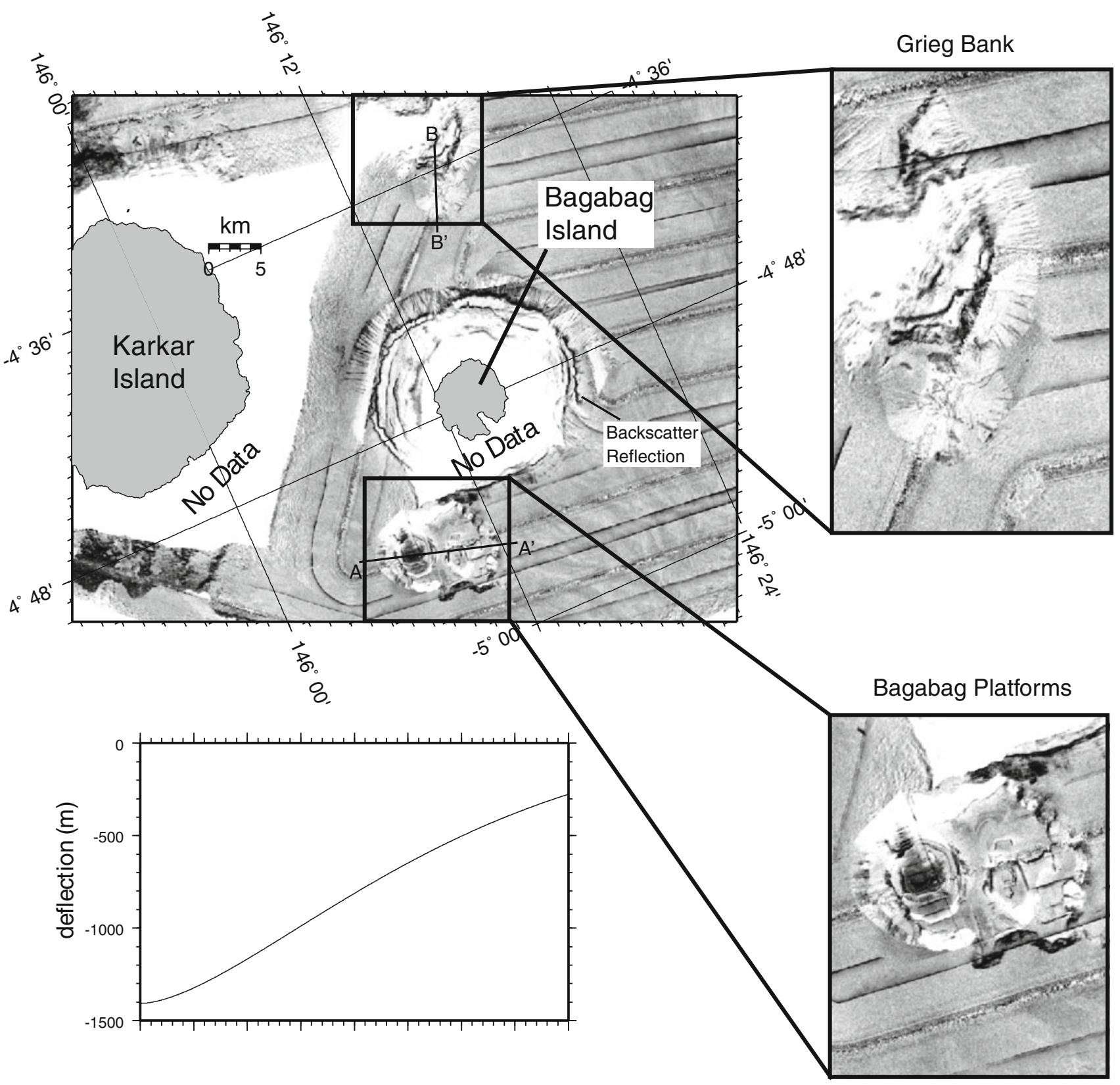

Fig. 5 Sidescan mosaic of Karkar Island and Bagabag Island (upper left). High backscatter is dark. Enlargements of Grieg Bank (upper right) and Bagabag Platforms (lower right). Calculated flexural deflection due to loading by Karkar Island for a crustal elastic thickness of $5 \mathrm{~km}$ (lower left) at same horizontal scale as main sidescan mosaic 
features are observed in sidescan imagery along a given slope-parallel transect of the island's flanks. These features are $\sim 0.5-2 \mathrm{~km}$ apart. The flanks of Bagabag Island have an average slope of as much as $15^{\circ}$ in the regions covered by multibeam data.

\section{Discussion of observations}

On Bagabag Platforms, southwest of Bagabag Island, each successive terrace steps inward, and each possesses a shallow, wide bulge around the rim, similar to those observed on the Kohala Terrace (Fig. 4; Campbell 1984). Additionally, the flanks of each terrace are slightly sinuous and have a high backscatter in sidescan imagery, similar to the drowned platforms observed in the Huon Gulf (Fig. 2). Additionally, the Bagabag Platforms bear some resemblance to the flat-topped volcanic cones observed elsewhere (Fornari and Campbell 1987; Clague et al. 2000). However, there is no evidence of rifting in this region, and flat-topped cones have not been reported with multiple tiers. Thus, it is unlikely the Bagabag Platforms represent a flat-topped cone. Also, carbonates and coral material were dredged from the Bagabag Platforms (Arculus and Yeats 2007). Around Bagabag Island and Grieg Bank, we observe sinuous, high backscatter, slope-perpendicular features in sidescan imagery (Fig. 5). These features appear similar to the sinuous, high backscatter, slope-perpendicular drowned carbonate platforms in the Huon Gulf (Fig. 2). The features around Bagabag Island and Grieg Bank are downslope of active shallow water reefs, similar to the drowned carbonate platforms in the Huon Gulf. Therefore, we interpret the features around Bagabag Island and Grieg Bank as drowned carbonate platforms.
The deepest terrace of the Bagabag Platforms is at a depth of 1,100 $\mathrm{m}$. The deepest high backscatter features on Bagabag Island and Grieg Bank are approximately $900 \mathrm{~m}$ deep and $1,100 \mathrm{~m}$ deep, respectively. We infer that approximately $900 \mathrm{~m}$ of relative subsidence has occurred at these locations since the carbonate platforms were active.

\section{Flexural modeling}

Three possible causes of subsidence at Bagabag Island include volcanic loading by Karkar, high sedimentation rates, and bending of the lithosphere related to the Finisterre collision (Fig. 6). Modeling of these scenarios provides an estimate of the magnitude of subsidence due to these causes. With this estimate, we can examine whether each of these hypotheses, alone or in combination, is sufficient to explain the amount of subsidence inferred from the sonar data.

\section{Modeling methods}

For the flexural models we used the point-load (volcanic loading), 2D infinite beam (sedimentary loading), and 2D semi-infinite beam (collisional loading) solutions to the elastic force balance equations (Hertz 1884; Wessel 1996; Watts 2001). For all model runs, we assumed Young's modulus equals $70 \mathrm{GPa}$ and Poisson's ratio equals 0.25. Varying these parameters did not significantly affect model outputs. In all cases, we modeled a range of plate elastic thicknesses, as the elastic thickness at the modeled locations is unknown.

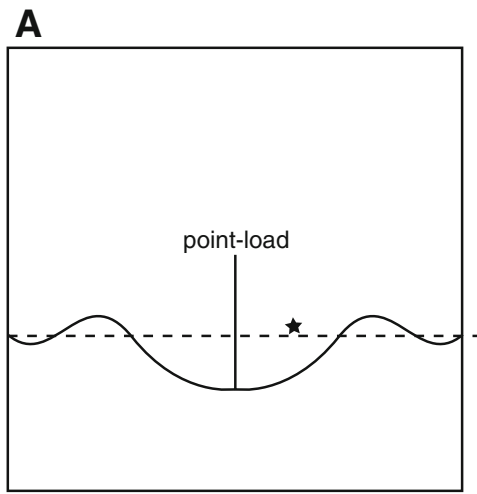

Point-load
B

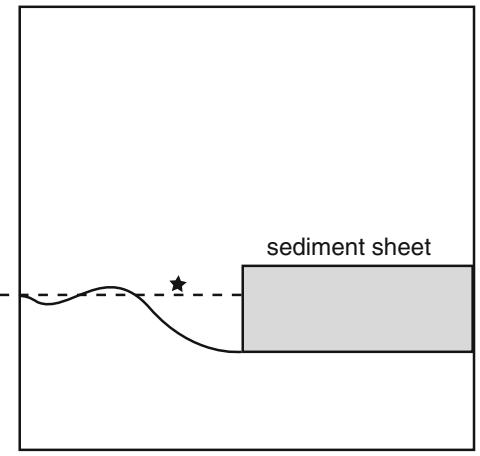

Sediment load

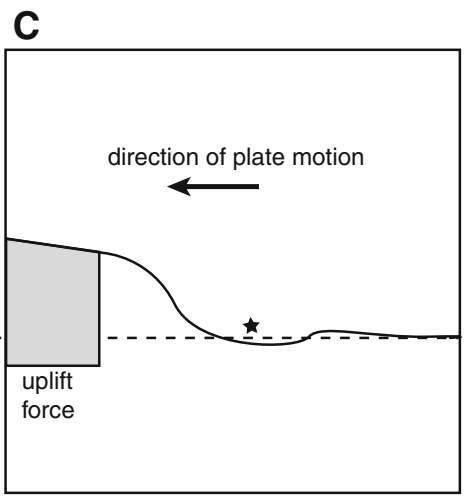

Terrane uplift
Fig. 6 Cartoons illustrating the three flexural model geometries used in this study. Not to scale. Dotted line represents unperturbed baseline. Note that secondary bulges/troughs are typically quite small, and are exaggerated in these figures. The star in each figure shows schematically where the Bagabag Platforms would be located in each model scenario. a Point-load approximating a volcanic source. Solution is circularly symmetric about the point-load. b Edge of a uniform sediment sheet.
The sheet extends infinitely to the right, and the out-of-page direction is held constant. c Buoyant uplift of terrane. The left edge of the figure represents the edge of a broken plate, with the out-of-page direction held constant. As collision continues, more of the overriding South Bismarck Plate will be subject to the uplift force. Thus, the flexural profile depicted above will move right relative to the Bagabag Platforms, meaning the platforms are presently subject to very slow uplift due to the collision 
The diameter of Karkar is approximately $35 \mathrm{~km}$ at its base. It rises from a maximum depth of $1,700 \mathrm{~m}$ to a maximum height of $1,840 \mathrm{~m}$ above sea level. The island is roughly cone-shaped. We modeled the island as a pointload corresponding to a volume of $1,100 \mathrm{~km}^{3}$ and a density of $2,500 \mathrm{~kg} / \mathrm{m}^{3}$. We note that a point-load will over-estimate the amount of subsidence. However, this over-estimate is very slight $(\sim 1 \%)$ compared to, for instance, a distribution of 20 equally spaced partial point-loads.

The Adelbert terrane is overriding the New Guinea mainland at a rate of about $20 \mathrm{~mm} /$ year in the vicinity of Bagabag, based on a relative pole of rotation for the South Bismarck Plate-Australian Plate at $4.18^{\circ} \mathrm{S}, 144.02^{\circ} \mathrm{E}$, with a rotation rate of 9 degrees/m.y. (Taylor 1979; Tregoning et al. 1998; Wallace et al. 2004). Uplift occurs along the Ramu-Markham Fault (Fig. 1). Towards the eastern end of the collision, the Ramu-Markham Fault dips to the north at about $45^{\circ}$ (Abers and McCaffrey 1994; Stevens et al. 1998). Lacking data on the fault geometry near the Adelbert terrane, we assume a similar fault dip. We used the semi-infinite (broken plate) solutions to the flexure equation to model the elastic response to uplift. We modeled the Adelbert terrane as a block $60 \mathrm{~km}$ wide and applied a buoyant force caused by the underlying plate in order to obtain approximately $1,500 \mathrm{~m}$ of uplift expected for late-Pleistocene convergence $(100 \mathrm{ka})$.

To model sedimentary loading, we constructed a $100 \mathrm{~km}$-wide layer of uniform density $\left(2,300 \mathrm{~kg} / \mathrm{m}^{3}\right)$. The thickness of the layer was $2 \mathrm{~km}$, based on a sedimentation rate of $10 \mathrm{~mm} / \mathrm{year}$ over $200 \mathrm{ka}$. We examined displacement $5 \mathrm{~km}$ from the edge of this layer.

\section{Modeling results}

The Bagabag Platforms, Bagabag Island, and Grieg Bank are all about $35 \mathrm{~km}$ from the center of Karkar Island. Model outputs for downward deflection at this distance due to volcanic loading of Karkar Island are summarized in Table 1, and a representative result is shown in Fig. 5. Despite varying the effective elastic thickness for the underlying lithosphere, the drowned carbonate platforms in this region always lie within the area of downwardly deflected crust. The maximum deflection that we modeled is $380 \mathrm{~m}$ for an effective elastic thickness of $5 \mathrm{~km}$.

The drowned platforms in the vicinity of Bagabag Island are at least $30 \mathrm{~km}$ from the edge of the Adelbert Terrane, with the Bagabag Platforms being the closest and Grieg Bank being the farthest. Model outputs for downward deflection at this distance due to uplift of the Adelbert Terrane by buoyant forcing of the under-riding plate are summarized in Table 1. The maximum downward deflection obtained by our simulation is small $(<20 \mathrm{~m})$, and occurs only for an elastic thickness less than $5 \mathrm{~km}$. Otherwise, the model predicts that uplift should occur.

\section{Discussion of flexural modeling}

The model for loading by Karkar Island assumes that the drowned carbonate platforms nearby predate the initiation of volcanic activity at Karkar. Even if this assumption is true, our model predicts that this loading can only account for a roughly half of the $900 \mathrm{~m}$ of relative subsidence inferred from the sidescan and multibeam data.

Additionally, the model predicts up to $180 \mathrm{~m}$ of uplift in this region due to the collision of the Adelbert Terrane with the New Guinea mainland. Specifically, as carbonate platforms approach the present location of collision at a rate of $20 \mathrm{~mm} / \mathrm{year}$, we expect a small increase in the rate of uplift that would start to counteract any local subsidence over the course of the development of the reef system. Over $100 \mathrm{ka}$, we expect roughly $2 \mathrm{~km}$ of convergence. The change in upward deflection over $2 \mathrm{~km}$ is roughly $20 \mathrm{~m}$ at a distance of $30 \mathrm{~km}$ from the edge of the terrane. Thus, we expect an actual uplift rate of roughly $0.2 \mathrm{~mm} / \mathrm{year}$.

Additional subsidence can be obtained, however, from sedimentary loading around Bagabag Island. Sedimentation rates in this region are high (Milliman 1995). For a sedimentation rate of $10 \mathrm{~mm} /$ year, with a sediment density of $2,300 \mathrm{~kg} / \mathrm{m}^{3}$, a subsidence rate of $\sim 6.8 \mathrm{~mm}$ /year is expected. This rate drops away from the loading as it is spread over a longer wavelength. For instance, about $5 \mathrm{~km}$ from the edge of a uniform layer of sedimentary loading on a lithosphere

Table 1 Flexural model outputs for downward deflection of Bagabag Platforms due to volcanic loading by Karkar

\begin{tabular}{|c|c|c|c|c|}
\hline $\begin{array}{l}\text { Crustal elastic } \\
\text { thickness }(\mathrm{km})\end{array}$ & $\begin{array}{l}\text { Downward deflection due } \\
\text { to volcanic loading } \\
\text { by Karkar }(\mathrm{m})\end{array}$ & $\begin{array}{l}\text { Downward deflection } \\
\text { due to sediment }(\mathrm{m})\end{array}$ & $\begin{array}{l}\text { Downward deflection } \\
\text { due to Adelbert uplift (m) }\end{array}$ & $\begin{array}{l}\text { Total downward } \\
\text { deflection }(\mathrm{m})\end{array}$ \\
\hline 5 & 380 & 500 & 20 & 900 \\
\hline 10 & 280 & 600 & -40 & 840 \\
\hline 15 & 190 & 660 & -40 & 810 \\
\hline 20 & 135 & 660 & -40 & 755 \\
\hline
\end{tabular}

Listed are the modeled flexural responses at the Bagabag Platforms at a range of crustal elastic thicknesses due to loading by Karkar Island, local sedimentation over $200 \mathrm{ka}$, and uplift of the Adelbert Terrane over $200 \mathrm{ka}$. The right-hand column lists total expected deflection from all sources 
with $15 \mathrm{~km}$ elastic thickness, we expect about $3 \mathrm{~mm} /$ year of subsidence. Over $200 \mathrm{ka}$ or more, this is sufficient to explain several $100 \mathrm{~m}$ of subsidence at Bagabag Island. Up to $2 \mathrm{~km}$ of sediment, combined with volcanic loading on Karkar Island and possibly increased density of the sub-sediment roots of the volcano may explain the total subsidence inferred from our data. According to seismic data described by Hamilton (1979), there may be as much as $2 \mathrm{~km}$ of sediment in the vicinity of Bagabag Island. However, the age of this sediment is unknown.

\section{Conclusions}

We interpret the concentric high backscatter features around Bagabag Island, the submarine platforms southwest of Bagabag Island, and the high backscatter features around Grieg Bank to be series of submerged carbonate platforms. From their depth we infer at least $900 \mathrm{~m}$ and as much as $1,100 \mathrm{~m}$ of subsidence has occurred at each of these locations since the deepest drowned platforms were active.

Flexural modeling of volcanic loading at these locations indicates that such a process could be responsible for a significant portion of the subsidence. However, the magnitude of relative subsidence due to volcanic loading appears to be about a factor of 2 less than the subsidence determined from the depth of the drowned platforms. Bending of the lithosphere due to the Adelbert and Finisterre collisions fail to contribute significantly to, and may even serve to counteract, any local subsidence. However, sedimentary loading in this region could be sufficient to explain the remaining subsidence we inferred at these locations if the carbonate platforms are sufficiently old.

Acknowledgments Funding for this research was provided by the Marine Geology and Geophysics section of the U.S. National Science Foundation, grant OCE-0327004 to E. Silver and S. Ward and grant OCE- 0328278 to N. Driscoll. Sidescan and multibeam data used in this study were acquired during cruise R/V Kilo Moana 0419. We thank Richard Arculus for sending us the Cruise Report of the R/V Southern Surveyor (06/2007) that describes the dredged carbonates from the Bagabag Platforms. We are grateful to the scientific party and ship's crew of the R/V Kilo Moana 0419 for their assistance in this project, and to the reviewers of this manuscript for their comments and suggestions.

Open Access This article is distributed under the terms of the Creative Commons Attribution Noncommercial License which permits any noncommercial use, distribution, and reproduction in any medium, provided the original author(s) and source are credited.

\section{References}

Abbott LD, Silver EA, Thompson PR, Filewicz MV, Schneider C, Abdoerrias (1994) Stratigraphic constraints on the development and timing of arc-continent collision in northern Papua New Guinea. J Sediment Res 64:169-183
Abers GA, McCaffrey R (1994) Active arc-continent collision: earthquakes, gravity anomalies, and fault kinematics in the Huon-Finisterre collision zone, Papua New Guinea. Tectonics 13(2):227-245

Arculus RJ, Yeats C (2007) Volcanism and tectonism of the South Bismarck microplate, Papua New Guinea. R/V Southern Surveyor Voyage Summary SS06/2007, CSIRO

Campbell JF (1984) Rapid subsidence of Kohala Volcano and its effect on coral reef growth. GeoMar Lett 4(1):31-36

Clague DA, Moore JG, Reynolds JR (2000) Formation of submarine flat-topped volcanic cones in Hawai'i. Bull Volcanol 62(3):214 233

Darwin C (1897) Coral reefs

Davies HL, Keene JB, Hashimoto K, Joshima M, Stuart JE, Tiffin DL (1987a) Bathymetry and canyons of the western Solomon Sea. Geo Mar Lett 6:181-191

Davies HL, Lock J, Tiffin DL, Honza E, Okuda Y, Murakami F, Kisimoto K (1987b) Convergent tectonics in the Huon Peninsula region, Papua New Guinea. Geo Mar Lett 7(3):143-152

Fornari DJ, Campbell JF (1987) Submarine topography around the Hawaiian Islands. US Geol Surv Prof Paper 1350:109-124

Galewsky J (1998) The dynamics of foreland basin carbonate platforms: tectonic and eustatic controls. Basin Res 10(4):409416

Galewsky J, Silver EA, Gallup CD, Edwards RL, Potts DC (1996) Foredeep tectonics and carbonate platform dynamics in the Huon Gulf, Papua New Guinea. Geology 24(9):819-822

Geist D, Diefenbach DA, Fornari DJ, Kurz MD, Harpp K, Blusztajn J (2008) Construction of the Galápagos platform by large submarine volcanic terraces. Geochem Geophys Geosyst 9:Q03015. doi:10.1029/2007GC001795

Grigg R, Grossman E, Earle S, Gittings S, Lott D, McDonough J (2002) Drowned reefs and antecedent karst topography, Au'au Channel, S.E. Hawaiian Islands. Coral Reefs 21(1):73-82

Hamilton W (1979) Tectonics of the Indonesian region. US Geol Surv Prof Paper 1078:231-260

Hertz H (1884) Ueber das Gleichgewicht schwimmender elastischer Platten. Annalen der Physik 258(7):449-455

Johnson RW, Taylor GAM, Davies RA (1972) Geology and petrology of quaternary volcanic islands off the north coast of New Guinea. Rec Bur Miner Resour Aust 21:1-127

Jones AT (1995) Geochronology of drowned Hawaiian coral reefs. Sediment Geol 99(3-4):233-242

McKee CO, Cooke RJS, Wallace DA (1976) 1974-75 Eruptions of Karkar volcano, Papua New Guinea. In: Johnson RW (ed) Volcanism in Australasia. Elsevier, Amsterdam, pp 173-196

Milliman JD (1995) Sediment discharge to the ocean from small mountainous rivers: the New Guinea example. Geo Mar Lett $15: 127-133$

Moore JG, Campbell JF (1987) Age of tilted reefs, Hawaii. J Geophys Res 92(B3):2641-2646

Pigram CJ, Davies HL (1987) Terranes and the accretion history of the New Guinea orogen. Bur Miner Resour J Aust Geol Geophys 10:193-211

Stern TA, Holt WE (1994) Platform subsidence behind an active subduction zone. Nature 368(6468):233

Stevens C, McCaffrey R, Silver EA, Sombo Z, English P, van der Kevie J (1998) Mid-crustal detachment and ramp faulting in the Markham Valley, Papua New Guinea. Geology 26(9):847-850

Taylor B (1979) Bismarck Sea: evolution of a backarc basin. Geology 7:171-174

Tregoning P (2002) Plate kinematics in the western Pacific derived from geodetic observations. J Geophys Res 107(B1):2020. doi: 10.1029/2001JB000406

Tregoning P, Lambeck K, Stoltz A, Morgan P, McClusky SP, van der Beek P, McQueen H, Jackson RJ, Little RP, Laing A, Murphy B 
(1998) Estimation of current plate motions in Papua New Guinea from global positioning system observations. J Geophys Res 103:12181-12203

Wallace L, Stevens C, Silver E, McCaffrey R, Loratung W, Hasiata S, Stanaway R, Curley R, Rosa R, Taugaloidi J (2004), GPS and seismological constraints on active tectonics and arc-continent collision in Papua New Guinea: Implications for mechanics of microplate rotations in a plate boundary zone. J Geophys Res 109, B05404. doi: 10.1029/2003JB002481
Watts AB (2001) Isostasy and flexure of the lithosphere. Cambridge University Press, Cambridge

Webster JM, Wallace L, Silver E, Applegate B, Potts D, Braga JC, Riker-Coleman K, Gallup C (2004) Drowned carbonate platforms in the Huon Gulf, Papua New Guinea. Geochem Geophys Geosyst 5:Q11008. doi:10.1029/2004GC000726

Wessel P (1996) Analytical solutions for 3-D flexural deformation of semi-infinite elastic plates. Geophys J Int 124:907-918 